Benzer, A. ve Ünsal, F. (2019). Konuşma öğretiminin program ve ders kitabı ekseninde uygulamaya yansıması. Ana Dili Eğitimi Dergisi, 7(3), 647-662.

$\begin{gathered}\text { Ana Dili Eğitimi Dergisi } \\ \text { Journal of Mother Tongue Education } \\ \text { www.anadiliegitimi.com }\end{gathered}$
Geliş/Received: 13.05 .2019 Kabul/Accepted: 27.06 .2019
Araștirma Makalesi / Research Paper

\title{
Konuşma Öğretiminin Program ve Ders Kitabı Ekseninde Uygulamaya Yansıması
}

\begin{abstract}
Ahmet BENZER*
Faruk ÜNSAL ${ }^{* *}$

Öz

Konuşma, dört temel beceri içerisinde en çok kullanılan ikinci beceridir. Konuşma becerisini kazandırılması sürecinde pek çok değişken etkilidir ve bu değişkenlerin konuşmayı ne derecede etkilediği konusunda yapılacak araştırmalar da araştırmacılara sürecin tasarımı konusunda araştırmacılara yön gösterecektir. Bu araştırmanın amacı da konuşma becerisinin öğretimine yönelik değişkenler ve Türkçe öğretmenlerinin bu değişkenler hakkındaki görüşlerini tespit etmektir. Bu amaç doğrultusunda araştırmacılar tarafından hazırlanan yarı yapılandırılmış görüşme formu kullanılmıştır. Araştırma, nitel araştırma desenlerinden olgu bilim deseni ile gerçekleştirilmiştir. Araştırmada Türkçe derslerinde kazandırılmaya çalışılan okuma, yazma, dinleme ve konuşma becerileri içinde en az konuşma becerisi üzerine olduğu görülmüştür. Ders kitaplarından alınan konuşma etkinlikleriyle ilgili öğretmenlerin yönerge eksikliği, öğrencinin ilgisini çekememe, uygulanmasının zor olması gibi nedenlerle etkinlikleri yetersiz görmekte, konuşma öğretimi kapsamında öğretmenler tarafından en çok "Tartışma" ve "Katılımlı Konuşma"nın kullanıldığı görülmüştür. Araştırma ile ders kitaplarındaki konuşma etkinliklerinin gerçek yaşamdan alınmış konuşma örnekleriyle zenginleştirilmiş, öğrencilerin ilgi ve seviyelerine uygun, yönergelerle desteklenmiş ve öğrencilerin sözel ifade gücünü artıııı nitelikte olması gerektiği sonucuna ulaşılmışır.
\end{abstract}

Anahtar Kelimeler: Konuşma Becerisi, Konuşma Öğretimi Sorunları, Öğretmen Görüşleri.

\section{Reflection of Speaking Skill Teaching to Practice on the Context of Program and Coursebook}

\begin{abstract}
Speech is the second most commonly used skill in four basic skills. Many variables are effective in the process of gaining speech skills, and research on how these variables affect speech will also guide researchers on the design of the process. For this purpose,this research's aim was to determine the variables related to speech education and to determine the opinions of Turkish teachers on these variables. For this purpose, semi-structured questionnaire prepared by the researchers was used. The research was carried out with phenomelogy which is a type of qualitative research design. Research in reading and trying to win the Turkish lessons, writing, listening and speaking skills were found to be in on at least conversational skills. It is seen that the teachers mostly use "Discussion" and "Speech Attended" within the scope of speech teaching, due to lack of instruction, speech failure from the textbooks, lack of instruction, and difficulty in implementation. It has been suggested by the teachers that the research and speech activities should be enriched with speech examples from the real life and emphasizing the features of the spoken language.
\end{abstract}

Keywords: Speaking Skills, Problems of Speaking Teaching, Teachers' Opinions.

\footnotetext{
* Doç. Dr., Marmara Üniversitesi, Atatürk Eğitim Fakültesi, Türkçe Eğitimi Bölümü, İstanbul, ahmetbenzer@gmail.com, ORCID: 0000-0003-3579-3699

** Yüksek Lisans Öğrencisi, Marmara Üniversitesi, Atatürk Eğitim Fakültesi, Türkçe Eğitimi Bölümü, İstanbul, farukunsal52@gmail.com, ORCID: 0000-0003-0879-2367
} 


\section{Giriş}

Dil, anlama (okuma, dinleme) ve anlatma (yazma, konuşma) başlıkları altında dört temel beceriyi içerisinde barındıır. Anlatmaya dayalı becerilerden olan konuşma; duygu, düşünce ve bilgilerin zihinde tasarlandıktan sonra seslerden oluşan dil aracılığıyla karşımızdakilere aktarılmasıdır (Demirel, 1999: 40; Ceran, 2012: 340). Günlük yaşam içerisinde bireyin diğer insanlarla olan iletişim ve etkileşiminde belirleyici bir role sahip olan konuşma, kişinin zihinsel gelişim, kişilik oluşumu ve toplumsal ilişkilerinin de bir yansıtıcısıdır (Sever, 2004: 23). Buna rağmen dört temel beceriden biri olan konuşma en çok kullandığımız becerilerden biri olmakla birlikte eğitim aşamasında üzerinde en az durulan beceridir (Özbay, 2005: 178; Uçgun, 2007: 59; Doğan, 2009: 186; Üner, 2010: 59; Topçuoğlu, 2011: 398). McDonough, Shaw ve Masuhara ise (2013: 156) konuşmanın, genellikle diğer becerilere göre daha değersiz olarak görüldüğünü belirtmiştir.

Konuşma öğretiminin nasıl gerçekleştirileceği konusu süregelen bir tartışmadır. Richards (1990: 76-77) konuşma öğretimini; çocukların, okula başlamadan önce aile ve çevrelerinden edindikleri dolaylı öğretim ve çocuğun hayatına okulun girmesiyle birlikte akıcı konuşma için belirli stratejiler ve süreçleri içeren dolaysız öğretim olmak üzere ikiye ayırmaktadır. Dolaysız öğretimde öğrencinin dikkati açık bir şekilde karşııklı konuşma kurallarına ve stratejilerine çekilir. Burada da çocukların güzel, doğru ve etkili konuşma becerisini kazanmalarına rehberlik edecek; özel olarak hazırlanmış konuşma etkinliklerinin önemi ortaya çıkmaktadır. Bu durum da akıllara Türkçe derslerinde uygulanan çalışmaların ve ders kitaplarında yer alan etkinliklerin niteliklerinin nasıl olduğu; yeni etkinlik türlerinin nasıl olacağı sorularını getirmektedir.

Bununla birlikte konuşma öğretiminin uygulama ağırlıklı olarak yürütülmesi gerektiği birçok çalışmada vurgulanmaktadır (Kurudayıoğlu, 2003: 296; Özbay, 2005: 2; Temizyürek, 2007:121; Doğan, 2009:190; Bulut, Açık ve Çiftçi, 2016: 145). Toplumsal yaşamda bireylerin konuşma becerisiyle ilgili yaşadığı kaygı, korku ve endişelerin giderilmesi ancak ilgi çekici, etkili konuşma etkinliklerinin gerçekleştirildiği düzenli bir eğitim anlayışıyla mümkün olacaktır (Tüzemen ve Kardaş, 2017). Konuşma öğretiminin uygulamaya dönük nasıl işlenebileceğine yönelik olarak Katchen (2004: 6) videoyu rol modellerinin gösterilmesini kolaylaştıran bir araç olarak ele almış ve rol model olarak videoyu kullanmanın sunum becerileri öğretimini kolaylaştıracağını belirtmiştir. Magasic (2017: 200) dil öğretiminde videonun öğrenci performansına olumlu yansıdığından ve öğrenciler için videonun dört ana faydası olduğundan bahseder. Bunlar; otantik dil, sözlü dil, dilötesi özellikler (jest, mimik, beden dili vs.) ve motivasyonel faydadır. Oradee (2012: 533) çalışmasında tartışma, problem çözme ve rol oynama modellerinin, öğrencilerin konuşma becerilerinin gelişmesine ve konuşmaya yönelik tutumlarının olumlu olarak değişmesine katkı yaptığını belirtmiştir. Šolcová (2011: 16) ortaokullarda dil (İngilizce) öğretimi ile ilgili yaptığı çalışmasında konuşma öğretiminde kullanılan metinlerin sadece 
yazılı olarak verilmesinin konuşma akıcılığında ilerleme sağlamayacağını belirtir. Bu nedenle de bir dilin konuşulan biçimini konuşulan metin örneklerini kullanarak öğretmenin, konuşmayı öğretmenin bir parçası olması gerektiğini belirtmiştir. Burada konuşulan dile ait konuşma biçimlerini olduğu gibi yansıtacak ögelerin (tekrarlar, duraklamalar, ses olayları, yarım cümleler, deyimler, yanlış başlangıçlar vs.) yer aldığı konuşma metinlerinin olmasının gerekliliği ortaya çıkmaktadır.

Ortaokul düzeyinde çocuklar her ne kadar konuşmayı öğrenmiş olarak okula gelse de çocukların konuşma becerilerinin Türkçe dersleriyle daha da geliştirilmesi öğretim programının temel hedefleri arasındadır. Bununla birlikte Öztürk ve Altuntaş (2012: 343) konuşmayı öğrenerek okula gelen çocuklarda konuşurken çekingenlik davranışı, kısa ve yetersiz konuşma, sesi ayarlayamama, dağınık konuşma, gereksiz şeyler söyleme, sözcük dağarcığının yetersiz olması, gereksiz sesler çıkarma, konuşurken gereksiz beden hareketleri yapma, telaffuz, vurgu ve tonlama hataları, kavrama eksikliği, anlatım yetersizliği gibi sorunların söz konusu olabileceğini ifade etmişlerdir. Arslan'ın (2012: 229) araştırmasında öğrencilere topluluk karşısında konuşma fırsatının yeterince veril(e)mediği için eğitim kurumlarımızın kendini rahatlıkla ifade edebilen bireyler yetiştir(e)mediği sonucuna ulaşıımıştır. Sebep olarak da konuşmaların az sayıdaki resmî törenlerde sadece iyi olan öğrencilere yaptırılması, belli sınavlara odaklanıldığı için konuşmanın ihmal edilmesi, sınıfta daha çok en başarılı görülen öğrencilere söz hakkı verilmesi, daha çok öğretmenin konuştuğu bir sınıf ortamının olması, öğrencilerin yanlış veya eksik cevap verdikleri zaman azarlanmaları gösterilmiştir.

\section{Yöntem}

\section{Araştırmanın Modeli}

Bu araştırma, nitel araştırma yöntemlerinden olgu bilim deseni ile gerçekleştirilmiştir. Yıldırım ve Şimşek (2013: 72) olgu bilimi, araştırmacı tarafından farkında olunan; fakat derinlemesine ve ayrıntılı bir bilgiye sahip olunmayan olgulara odaklanan desenler olarak tanımlamaktadırlar. Bu araştırmada Türkçe öğretmenlerinin ortaokul Türkçe derslerinde konuşma becerisi ile ilgili yapılan çalışmalar konusundaki görüşlerinin neler olduğu olgusu araştırılmıştır. Araştırmada kullanılan görüşme formu her ne kadar dijital ortamda gönderilmiş olsa da sorular içerisinde öğretmenlere, cevaplarına göre değişen farklı seçenekler de sunulduğu için yarı yapılandırılmış olarak kabul edilmektedir.

\section{Araştırma Grubu}

Araştırmaya katılan 40 Türkçe öğretmeninin cinsiyet, mesleki tecrübe, eğitim durumu ve mesleğiyle ilgili eğitimlere katıım oranı şu şekildedir: 
Ahmet BENZER, Faruk ÜNSAL

Tablo 1. Araştırmaya katılan Türkçe öğretmenlerinin cinsiyet, mesleki tecrübe, eğitim durumu ve mesleğiyle ilgili eğitimlere katılım durumları

\begin{tabular}{|c|c|c|c|}
\hline Özellikler & Gruplar & Frekans (f) & Yüzde (\%) \\
\hline \multirow{2}{*}{ Cinsiyet } & Kadın & 19 & 47,5 \\
\hline & Erkek & 21 & 52,5 \\
\hline \multirow{4}{*}{ Mesleki Tecrübe } & $0-5$ & 13 & 32,5 \\
\hline & $5-10$ & 22 & 55 \\
\hline & $10-15$ & 4 & 10 \\
\hline & $15+$ & 1 & 2,5 \\
\hline \multirow{2}{*}{ Eğitim Durumu } & Lisans & 37 & 92,5 \\
\hline & Yüksek Lisans & 3 & 7,5 \\
\hline \multirow{2}{*}{$\begin{array}{l}\text { Mesleğiyle Iilgili } \\
\text { Katılım Oranı }\end{array}$} & Evet & 21 & 52,5 \\
\hline & Hayır & 19 & 47,5 \\
\hline
\end{tabular}

Veri Toplama Araçları

Araştırmada veri toplama aracı olarak araştırmacılar tarafından geliştirilen yarı-yapılandırılmış görüşme formu kullanılmıştır. Hazırlanan form, iki öğretmen ve iki alan uzmanının, görüşleri ve önerileri doğrultusunda düzenlenmiş, yeni sorular eklenip gereksiz sorular çıkartılmıştır. Daha sonra yapılan ön uygulama sonucunda, soruların bir kısmında düzeltmeler yapılmış ve forma son şekli verilmiştir. Görüşme formunda yer alan sorulardan 1, 8, 9, 10 ve 11. sorular sıralama tipi; 3, 4, 5, 6, 7 ve 14. sorular açık uçlu; 2 . soru evet-hayırlı; 12 ve 13. sorular ise birden fazla cevaplı sorulardan oluşmaktadır.

\section{Verilerin Toplanması}

Araştırma için gönüllülük esası göz önünde bulundurularak seçilen 40 Türkçe öğretmenine yarı-yapılandırılmış görüşme formu uygulanmıştır. Formu öğretmenlere e-posta ile gönderilmiştir. Elde edilen verilerle konuşma öğretimine yönelik değişkenlerin tespiti ve Türkçe öğretmenlerinin bu değişkenler hakkındaki görüşlerini tespit etmek amaçlanmıştır.

\section{Verilerin Analizi}

Araştırmanın veri toplama aracının farklı tipte sorulardan oluşması nedeniyle verilerin değerlendirilmesinde içerik analizi kullanılmıştır. İçerik analizi, sözel, yazılı ve diğer materyallerin içerdiği mesajı anlam ve/veya dilbilgisi açııından nesnel ve sistematik olarak sınıflandırma, sayılara dönüştürme ve çıkarımda bulunma yoluyla sosyal gerçeği araştıran bilimsel bir yaklaşımdır (Tavşancıl ve Aslan, 2001: 22). Oluşturulan kodlar, bir araya getirilerek ortak yönleri bulunmuş, böylece araştırma bulgularının ana hatlarını oluşturacak temalar (kategoriler) ortaya çıkarılmıştır. Belirlenen temalar altındaki kodlar birbirleriyle ilişkili biçimde açıklanarak yorumlanmış ve araştırmanın amacı doğrultusunda sonuçlar ortaya konulmuştur. 


\section{Bulgular}

Çalışmanın bulgular kısmı konuşma öğretimini etkileyen değişkenler dikkate alınarak dört alt başlıkta toplanmıştır. Öğretmenler her bir başlıkta görüşlerini birden fazla ifadeyle belirttikleri için tablolardaki ifade sıklıkları bazen öğretmen sayısını geçebilmiştir.

\section{Konuşma Becerisinin Mevcut Beceriler Arasındaki Önemi}

\section{Dört Temel Dil Becerileri Eğitiminin Kullanımı Hakkında Öğretmen Görüşleri}

Türkçe derslerinde dört temel dil becerilerinin kullanılma sıklığına göre sıralandığı soruda araştırmaya katılan 40 Türkçe öğretmeninden yalnızca \%20'si (8) konuşma becerisini birinci sırada gösterirken \%15'i (6) ikinci sırada, \%30'u (12) üçüncü sırada, \%35'i (14) ise dördüncü sırada göstermiştir. Konuşma dinlemeden sonra en çok kullanılan beceri olmasına rağmen bu durumun uygulamada farklı olduğu görülmektedir.

\section{Ders Kitaplarındaki Konuşma Becerisi Eğitimi}

Ders Kitaplarında Yer Alan Konuşma Etkinlikleri Hakkında Öğretmen Görüşleri

Öğretmenlerin ders kitaplarında yer alan konuşma etkinliklerine yönelik görüşlerinden elde edilen kodlar Tablo 2'de gösterilmiştir.

Tablo 2. Ders kitaplarında yer alan konuşma etkinlikleri hakkında öğretmen görüşleri

\begin{tabular}{llcc}
\hline & \multicolumn{1}{c}{ Kodlar } & Sıklık & Yüzde \\
\hline & Etkinlikler öğretmene ve öğrenciye rehberlik etmeli, aşamalı olmalı. & 13 & 32,5 \\
Olumsuz & Ders kitabındaki konuşma etkinliklerinin sınıfta uygulanması zor. & 8 & 20 \\
& Öğrencinin ilgisini çekmiyor, öğrenciyi istekli kılmıyor, öğrenci & 6 & 15 \\
& seviyesine uygun değil. & 7 & 17,5 \\
\hline Olumlu & Etkinlikler güzel ve yeterli & 6 & 15 \\
& Diğer & & \\
& &
\end{tabular}

Yukarıda tabloda görüldüğü gibi öğretmenler Türkçe ders kitabında sunulan konuşma etkinliklerini \%67,5 (27) oranında yetersiz görmüşlerdir. Bu noktada etkinliklerin iyileştirilmesi gerçeği ortaya çıkmaktadır. Öğretmenlerin konuyla ilgili örnek ifadeleri şöyledir:

Ö19: Etkinlikler kısmen kalitelidir. Etkinliğin niteliğini öğretmenin dersteki yönlendirmeleri, katkıları ve oluşturacağı konuşma ortamı da belirleyecektir.

Ö23: Öğrencinin zihninde hemen bir şeyler oluşması bu sorularla mümkün olmuyor. Görsellik, teknoloji olması gerekiyor. Çocuk bu tarz sorulara cevap vermek istemiyor, çocuğu zorla konuşturmaya çalışıyorum.

Ders Kitabındaki Konuşma Etkinliklerine Ait Yönlendirmelerin Yeterliliği

Ders kitabında yer alan konuşma etkinliklerine ait yönlendirmelerle ilgili öğretmen görüşlerinden elde edilen kodlar Tablo 3'te gösterilmiştir. 
Ahmet BENZER, Faruk ÜNSAL

Tablo 3. Ders kitabındaki konuşma etkinliklerine ait yönlendirmelerin yeterliliği hakkında öğretmen görüşleri

\begin{tabular}{llcc}
\hline & \multicolumn{1}{c}{ Kodlar } & Sıklık & Yüzde \\
\hline \multirow{2}{*}{ Olumsuz } & Yönergeler, rehberlik etmede yetersiz & 23 & 57,5 \\
& Kılavuz kitapların olması faydalıydı & 3 & 7,5 \\
\hline \multirow{2}{*}{ Olumlu } & Yönergeler yeterli & 10 & 25 \\
& Yönergeler daha açıklayıcı olmalı & 4 & 10 \\
\hline
\end{tabular}

Yukarıda tabloda görüldüğü gibi öğretmenler konuşma etkinliklerindeki yönlendirmeleri \%65

(26) oranında yetersiz görmüşlerdir. Yeterli görenlerden \%10 (4) oranında öğretmen ise yönergelerin daha açıklayıcı olması yönünde görüş bildirmişlerdir. Öğretmenlerin konuyla ilgili örnek ifadeleri şöyledir:

Ö6: Hayır. Daha ayrıntı yönlendirme yapılmalı. Konuşmaya başlarken, konuşmayı bitirirken öğrenciden neler bekliyorsak kitap bize biz de öğrencilere anlatmalıyız.

Ö37: Evet, rehberlik ediyor. Ancak daha ayrıntılı değerlendirme formları ve yönlendirmeler konulabilir.

Öğretmenlerin Ders Kitaplarındaki Konuşma Etkinliklerini Uygularken Karşılaştıkları Sorunlar

Etkinliklerin uygulanmasında karşılaşılan sorunlarla ilgili öğretmen cevapları Tablo 4'te verilmiştir.

Tablo 4. Öğretmenlerin konuşma etkinliklerini uygularken karşılaştıkları sorunlar

\begin{tabular}{lcc}
\hline \multicolumn{1}{c}{ Kodlar } & Sıklık & Yüzde \\
\hline Etkinliklerin öğrencilerin ilgisini çekmemesi, öğrenciyi istekli kılmaması & 11 & 20 \\
Etkinliklerin öğrenci seviyesine uygun olmaması & 10 & 18 \\
Etkinliklerin uygulama aşamalarının eksik olması & 6 & 11 \\
Öğrencilerin konuşmada zorlanması & 6 & 11 \\
Etkinliklerin tekdüze olması & 6 & 11 \\
Öğrencilerdeki özgüven eksikliği & 6 & 11 \\
Sınıf mevcutlarının fazla olması ve zaman yetersizliği & 5 & 9 \\
Öğrencilerin kısa cevaplar verip uzun konuşma yapmaması & 3 & 5 \\
Öğrencilerin dinleme alışanlıklarının olmaması & 2 & 4 \\
\hline
\end{tabular}

*Öğretmenler birden fazla cevap verdiklerinden frekanslar cevaplayıcı sayısından yüksektir.

Yukarıda tabloda görüldüğü gibi öğretmenlerin \%20'si (11) uygulama aşamasında en çok karşılaştıkları sorunu 'Etkinliklerin öğrencilerin ilgisini çekmemesi' olarak ifade etmişlerdir. Aşağıda yer verilen alıntılarda öğretmenler konuşma etkinliklerini uygularken karşılaştıkları zorlukları dile getirmişlerdir.

Ö6: Konu ilgilerini çekmediği için konuşmalarını çok kısa tutuyorlar. Yeterince dönüt alamıyoruz.

Ö9: Sözcükleri telaffuz etmekte zorlanmaları, jest ve mimiklere yeteri kadar önem vermemeleri. 
Konuşma Öğretiminin Program ve Ders Kitabı Ekseninde Uygulamaya Yansıması

Türkçe Dersi Öğretim Programında (2018) Konuşma Öğretimi

\section{Öğretmenlerin Yaptıkları Etkinlik Türleri}

Öğretmenlerin yaptıkları konuşma etkinlikleri ile ilgili cevapları Tablo 5'te gösterilmiştir.

Tablo 5. Konuşma becerisinin geliştirilmesine yönelik yapılan etkinlikler

\begin{tabular}{lcc}
\hline \multicolumn{1}{c}{ Kodlar } & Sıklık & Yüzde \\
\hline Hazırlıklı konuşma & 11 & 21 \\
Güncel, ilgi çekici, serbest bir konuda konuşma & 9 & 17 \\
Ders içi etkinliklerde söz hakkı verme & 9 & 17 \\
Hazırlıksız konuşma & 8 & 15 \\
Drama & 5 & 10 \\
Tartışma & 5 & 10 \\
Diğer & 3 & 6 \\
Seslendirme çalışmaları & 2 & 4 \\
\hline
\end{tabular}

*Öğretmenler birden fazla cevap verdiklerinden frekanslar cevaplayıcı sayısından yüksektir.

Yukarıda tabloda görüldüğü gibi öğretmenlerin \%21'i (11) en çok 'Hazırlıklı konuşma' etkinliğini uygulamaktadır. \%17'si (9) ise "Söz hakkı verme"yi konuşma etkinliği olarak nitelemiştir. Aşağıda yer verilen alıntılarda öğretmenler konuşma becerisini geliştirmeye yönelik yaptıkları çalışmaları dile getirmişlerdir.

Ö11: Genellikle konuşma becerisi ile ilgili olarak metinden bağımsı konuşma çalışması yaptırmaya çalışıyorum. Metinde verilen etkinlik ilgi çekici olmuyor. Mesela erkek öğrencilerle futbol konusunda konuşma becerisi etkinliği yapmak daha verimli oluyor.

Ö30: Drama, canlandırma vb. teknikleri kullanarak. Metni, tiyatro metnine çevirip daha sonra rol yaptırarak öğrencileri konuşturuyorum.

Programdaki Yöntem ve Teknikler Hakkında Öğretmen Görüşleri

Öğretmenlerin program kapsamında ve dışında kullandıkları yöntemlere dair soruya verdikleri cevaplar Tablo 6'da gösterilmiştir.

Tablo 6. Öğretmenlerin en çok kullandıkları ilk beş yöntem ve teknik

\begin{tabular}{llcc}
\hline & \multicolumn{1}{c}{ Yöntem/Teknikler } & Sıklık & Yüzde \\
\hline & Hazırlıksız Konuşma & 25 & 13 \\
& Katılımlı Konuşma & 25 & 13 \\
& Tartışma & 24 & 12 \\
& Yaratıcı Konuşma & 23 & 11 \\
& Hazırlıklı Konuşma & 22 & 11 \\
Programdaki Yöntem & Serbest Konuşma & 20 & 10 \\
ve Teknikler & Empati Kurma & 14 & 7 \\
& Eleştirel Konuşma & 12 & 6 \\
& Güdümlü Konuşma & 11 & 6 \\
& Kelime ve Kavram Havuzundan Seçerek Konuşma & 9 & 5 \\
& İkna Etme & 8 & 4 \\
\hline Programın Dışında & Hafızada Tutma & 3 & 2 \\
\hline
\end{tabular}




\begin{tabular}{llcc}
\hline Yöntem ve Teknikler & Dramatizasyon & 8 & 21 \\
& Seslerini Doğru ve Etkin Kullanma & 8 & 21 \\
& Oyun & 5 & 13 \\
& Diğer & 3 & 8 \\
\hline
\end{tabular}

Konuşma Öğretimini Geliştirmeye Yönelik Amaç ve Kazanımlar

Araştırmaya katılan öğretmenlerin konuşma becerisini geliştirmede kazanımlara verdikleri önem dereceleri şu şekildedir:

Tablo 7. Konuşma öğretimi kazanımları hakkında öğretmen görüşleri

\begin{tabular}{|c|c|c|}
\hline Maddeler & Sıklık & Yüzde \\
\hline Kendini sözlü olarak ifade etme alışkanlığı kazanma & 24 & 14 \\
\hline Konuşmalarında beden dilini etkili bir şekilde kullanır. & 24 & 14 \\
\hline Konuşmalarında sesini etkili kullanma & 19 & 11 \\
\hline Kelimeleri anlamlarına uygun kullanır. & 18 & 10 \\
\hline Hazırlıklı konuşma yapar. & 18 & 10 \\
\hline Hazırlıksız konuşma yapar. & 15 & 9 \\
\hline Konuşma kurallarını uygulama & 13 & 8 \\
\hline Konuşma stratejilerini uygular. & 11 & 7 \\
\hline Konuşmalarında uygun geçiş ve bağlantı ifadelerini kullanır. & 9 & 5 \\
\hline Kendi konuşmasını değerlendirme & 6 & 4 \\
\hline $\begin{array}{l}\text { Konuşmalarında yabancı dillerden alınmış, dilimize henüz } \\
\text { yerleşmemiş kelimelerin Türkçelerini kullanır. }\end{array}$ & 6 & 4 \\
\hline Bütün kazanımlar eşit öneme sahip. & 6 & 4 \\
\hline
\end{tabular}

*öğretmenler birden fazla cevap verdiklerinden frekanslar cevaplayıcı sayısından yüksektir.

Yukarıda tabloda görüldüğü gibi konuşma becerisi kazanımları içerisinde öğretmenler en çok "Kendini sözlü olarak ifade etme alışkanlığı kazanma" ve "Konuşmalarında beden dilini etkili bir şekilde kullanır." kazanımlarını öncelikli olarak görmektedir.

\section{Konuşma Öğretiminde Karşılaşılan Sorunlar Hakkında Öğretmen Görüşleri}

Araştırmaya katılan öğretmenlerin konuşma öğretiminde karşılaştıkları sorunlara dair cevapları şöyledir:

Tablo 8. Konuşma öğretiminde karşılaşılan sorunlar hakkında öğretmen görüşleri

\begin{tabular}{|c|c|c|}
\hline Maddeler & Sıklık & Yüzde \\
\hline Materyal çeşitliliğinin az olması dikkat çekiciliği olumsuz etkilemektedir. & 26 & 15 \\
\hline $\begin{array}{l}\text { Konuşma etkinliklerinde ön hazırlık, uygulama ve değerlendirme bölümleri } \\
\text { olmaması uygulamada öğretmen ve öğrencilere zorluk yaşatmaktadır. }\end{array}$ & 24 & 13 \\
\hline Gerçek yaşamdan kopuk konularla konuşma eğitimi yapılmaktadır. & 21 & 12 \\
\hline Ders kitaplarından yer alan konuşma becerisi etkinlikleri yetersizdir. & 18 & 10 \\
\hline $\begin{array}{l}\text { Konuşma ile ilgili kullanılan ortak bir kaynak eserin olmaması uygulamada } \\
\text { zorluğa sebep olur. }\end{array}$ & 15 & 8 \\
\hline Sınıf mevcutlarının kalabalık olması. & 15 & 8 \\
\hline $\begin{array}{l}\text { Öğretim programında konuşma becerisi diğer becerilere göre inmal } \\
\text { edilmektedir. }\end{array}$ & 12 & 7 \\
\hline Etkinlikler esnasında sınıf yönetiminin zorlaşması. & 11 & 6 \\
\hline $\begin{array}{l}\text { Müfredatta konuşma becerisi ile ilgili yer alan kazanımların } \\
\text { eksik/yetersizdir. }\end{array}$ & 9 & 5 \\
\hline $\begin{array}{l}\text { Müfredatta/yıllık planda konuşma etkinlikleri için gereken zaman } \\
\text { ayrılmamıştır. }\end{array}$ & 9 & 5 \\
\hline Konuşma etkinlikleri tekdüzedir. & 7 & 4 \\
\hline
\end{tabular}


Müfredatta gereksiz yöntem ve tekniklerin bulunması uygulamada eksikliğe neden olmaktadır.

Konuşma etkinliklerinin süresinin belirsizliği.

Herhangi bir zorluk yaşandığını düşünmüyorum.

5

5

1
3

3

1

Yukarıda tabloda görüldüğü gibi konuşma öğretiminde zorluk yaşanmadığını sadece bir öğretmen ifade etmiştir. Öğretmenler en çok karşılaştıkları sorunları 'Materyal çeşitliliğinin az olması', 'Konuşma etkinliklerinde ön hazırlık, uygulama değerlendirme bölümleri olmaması' ve 'Konuların gerçek yaşamdan kopuk olması' şeklinde ifade etmişlerdir.

\section{Ideal Konuşma Öğretimi Hakkındaki Öğretmen Görüşleri}

\section{Konuşma Öğretimini Geliştirmeye Yönelik Öğretmen Görüşleri}

Öğrencilerin konuşma becerilerini geliştirmeye yönelik olarak seçeneklerde sunulan cevaplar ve cevapların öğretmenler tarafından işaretlenme sıklıkları şu şekildedir:

Tablo 9. Konuşma öğretimini geliştirmeye yönelik öğretmen görüşleri

\begin{tabular}{lcc}
\hline \multicolumn{1}{c}{ Maddeler } & Sıklık & Yüzde \\
\hline Gerçek hayatın içinden seçilmiş otantik konu ve materyaller kullanılabilir. & 34 & 85 \\
Dramatizasyon (Rol oynama, Tiyatro, Yaratıcı drama vs.) çalışmalarına yer & 31 & 77,5 \\
verilebilir. & 30 & 75 \\
Konuşma becerisine yönelik etkinlikler işlevsel bir şekilde hazırlanabilir. & 25 & 62,5 \\
Etkinlik örnekleri artırılabilir. & 24 & 60 \\
Konuşma becerisini teknolojiyle birleştirecek materyaller hazırlanabilir. & 23 & 57,5 \\
Ayrıntılı (Konuşma öncesi, esnası ve sonrası) etkinlik tasarımları hazırlanabilir. & 21 & 52,5 \\
Konuşma becerilerinin uygulanması için daha fazla süre verilebilir. & 3 & 7,5 \\
Şu an yapılan uygulamalar yeterli. & 1 & 2,5 \\
Örnek konuşmalar sınıfta izletilebilir. & & 75 \\
\hline
\end{tabular}

* Öğretmenlerin birden fazla cevap vermeleri neticesinde frekanslar cevaplayıcı sayısından yüksek durumdadır.

Yukarıda tabloda görüldüğü gibi \%85 (34) oranında öğretmen konuşma öğretimini geliştirmek için 'Gerçek hayatın içinden seçilmiş otantik konu ve materyaller kullanılabilir.' fikrini öne sürmüştür. Ayrıca sadece \%7,5 (3) oranında öğretmen şu an yapılan uygulamaları yeterli görmektedir.

\section{Etkinliklerde Aranan Özelliklerle ilgili Öğretmen Görüşleri}

Öğretmenlerin ders kitaplarındaki konuşma etkinliklerinin nasıl olması gerektiğine yönelik görüşlerinden elde edilen kodlar Tablo 10' da gösterilmiştir

Tablo 10. Öğretmenlere göre konuşma etkinliklerinde aranan özellikler

\begin{tabular}{lcc}
\multicolumn{1}{c}{ Kodlar } & Sıklık & Yüzde \\
\hline Gerçek hayatla ilgili otantik konular seçilmeli & 13 & 28 \\
Öğretmen ve öğrenciye rehberlik etmeli, aşama-aşama belirtilmeli & 8 & 17 \\
Öğrenci seviyesine uygun olmalı & 6 & 13 \\
Öğrencinin ilgisini çekmeli & 5 & 10 \\
Teknolojik materyalleri kullanmaya fırsat tanımalı. & 5 & $10)$ \\
Konuşma öncesi hazırlık aşaması olmalı & 5 & 10 \\
Örnek konuşmalar sınıfta izletilmeli & 3 & 6 \\
\hline
\end{tabular}

* Öğretmenlerin birden fazla cevap vermeleri neticesinde frekanslar cevaplayıcı sayısından yüksek durumdadır. 
Yukarıda tabloda görüldüğü gibi öğretmenlerin konuşma etkinliklerinde en çok aradığı özellik gerçek hayatla ilgili otantik konuların kullanılmasıdır. Bununla birlikte üç öğretmen cevabında yer alan örnek konuşmaların sınıfta izletilmesi de farklı bir bakış açısı göstermesi bakımından önemlidir. Aşağıda yer verilen alıntılarda öğretmenler konuşma etkinliklerinde aradıkları özellikleri dile getirmişlerdir.

Ö15: Konuşma etkinliklerinin yaşamın içinden örneklerle sunulması tercihimdir. Öğrencileri uygulamalara yönlendiren bunu yaparken de konuşma etkinliklerini öne çıkaran etkinlikler yapılmalıdır.

Ö20: Örnek konuşmacı ve dinleyici görselleri ile hedef ve kazanım daha açık ve belirgin hale getirilebilir.

Konuşma Etkinliklerinin Uygulanma Zamanıyla Ilgili Öğretmen Görüşleri

Araştırmaya katılan 40 öğretmenden 22'si (\%55) konuşma etkinliklerinin ders akışı içerisinde diğer becerilerle birlikte verilmesini yeterli görürken 16 sı (\%40) konuşma etkinliklerinin ayrı bir ders saati içerisinde konuşma becerisi özel olarak ele alınarak yapılması gerektiğini ifade etmiştir. iki öğretmen (\%5) ise konuşma etkinliklerinin zamanının yerine göre değişebileceğini, bazen bir ders saati bazense daha kısa sürebileceğini ifade etmişlerdir.

\section{Tartışma ve Sonuç}

Bu araştırmada, Türkçe öğretmenlerinin Türkçe dersi işleniş sürecinde konuşma öğretimine yönelik yapılan çalışmalara ilişkin görüşlerini tespit etmek amaçlanmıştır.

Ders kitabında sunulan konuşma etkinlikleriyle ilgili öğretmen görüşlerinden elde edilen bulgular ışığında öğretmenlerin \%67'sinin yönerge eksikliği, öğrencinin ilgisini çekememe, fazla zaman gerektirme gibi nedenlerden ötürü ders kitabında yer alan etkinlikleri yetersiz bulduğu görülmüştür. Bu ciddi bir problemdir alanda yapılan taramalarda kaynakların bu noktada birleştiği görülmektedir (Temizyürek, 2007: 129; Doğan, 2009: 185; Büyükikiz ve Hasırcı, 2013: 61). Bu da ders kitaplarında yer alan konuşma etkinliklerinde bu eksikliklerin giderilmesi gerektiğine işaret etmektedir. Kurudayığlu (2003: 307) sınıfın seviyesi ve kazanımlar göz önünde bulundurularak iyi yapılandırılmış etkinliklerle öğrencilerin konuşma becerilerinin âdeta oyun havası içinde geliştirilebileceğini belirtir.

Ders kitabında yer alan yönlendirmelerin yeterliği ile ilgili öğretmenlerin \%65’i etkinliklerdeki yönergelerin yetersiz olduğunu ifade etmişlerdir; ancak Erden (2014: 228) konuşma öğretimi ile ilgili öğretmenlerle yaptığı araştırmasında, konuşma etkinliklerindeki yönlendirmelerin öğretmenler tarafından yeterli görüldüğünü belirtmiştir. Araştırma sonuçları arasındaki bu farklııı̆ın sebebinin Erden'in çalışmasının gerçekleştiği dönemde (2014) kılavuz kitapların kullanılıp bu çalışmanın 
gerçekleştirildiği dönemde (2019) kullanılmaması olduğu düşünülmektedir. Araştırmada olumlu görüş bildiren öğretmenlerin de $\% 10^{\prime} u$ yönlendirmeleri yeterli bulmakla birlikte zenginleştirilmesinin yerinde olacağı yönünde görüş bildirmişlerdir. Öğretmenlerin görüşlerine benzer şekilde Brown, A. L. (1994: 278-282), Doğan (2009: 195), Lüle Mert (2014: 30-31), Kardaş ve Tunagür (2015: 187) de çalışmalarında konuşma etkinliklerini yönergelerle birlikte vermişlerdir.

Ders kitaplarındaki konuşma etkinliklerini uygularken karşılaşılan sorunlarla ilgili olarak öğretmenlerin \%20'si etkinliklerin öğrencilerin ilgisini çekmemesini, $\% 18^{\prime} i$ ise etkinliklerin öğrenci seviyesine uygun olmamasını en çok zorlandıkları noktalar olarak ifade etmişlerdir. Büyükikiz ve Hasırcı (2013: 61) konuşma öğretiminin oyun, uygulama ve eğitim ağılıklı olarak öğrenciye hitap edici şekilde verilmesi gerektiğini belirtmiştir. Benzer olarak Uçgun (2007: 66) konuşma öğretimini geliştirmede tören konuşmalarının, dramatizasyon çalışmalarının, çeşitli diyaloglar oluşturmanın, eğitsel oyunlar ile çeşitli resim ve fotoğraflardan yararlanmanın konuşmayı daha zevkli hâle getireceğini ifade etmiştir.

Türkçe derslerinde öğretmenlerin yaptıkları konuşma etkinliklerine dair öğretmen cevapları incelendiğinde her ne kadar Türkçe Öğretim Programı'nda belirtilen yöntemlerin Türkçe derslerinde eşit şekilde kullanılması gerektiği öngörülse de öğretmen cevapları içerisinde programdaki birçok yöntemin yer almadığı görülmektedir. Öğretmenler tarafından en çok kullanılan yöntemin \%21 oranında 'hazırlıklı konuşma' olduğu görülmektedir. Bununla birlikte öğretmenlerinin \%17'sinin öğrencilerdeki konuşma becerisini geliştirmek için yaptıkları etkinliğin 'ders içi etkinliklerde söz hakkı verme' ile sınırlı kalması konuşma öğretiminin ne denli sığ kaldığını bizlere göstermektedir. Benzer şekilde Topçuoğlu (2012: 741) konuşma öğretiminin öğrencinin kendisine sorulan sorulara verdiği cevaplardan ibaret olmaması gerektiğini ifade ederek Türkçe ders kitabındaki sorulara cevap verdirme yoluyla yapıldığı düşünülen konuşma etkinlikleriyle öğretmenlerin kolaya kaçtığını belirtmektedir.

Türkçe Dersi Öğretim Programında belirtilen yöntem ve tekniklerle ilgili öğretmen görüşlerinden elde edilen bulgular ışığında öğretmenler tarafından en çok "Hazırlıksız Konuşma" ve “Katılımlı Konuşma”nın kullanıldığı görülmektedir. Gün (2018: 122) ise tezinde konuşma öğretiminde öğretmenler tarafından en çok soru-cevap yönteminin kullanıldığı sonucuna ulaşmıştır. Ön çalışmaya gerek duyulmaması ve öğretmen tarafından özgürce seçilen bir konuda konuşma yapılabilmesi öğretmen görüşlerinden elde edilen bulgular ışığında bu tercihlerin sebepleri olarak görülmektedir.

Öğretim programında belirtilenlerin dışında alternatif yöntem ve tekniklerden "Dramatizasyon" ve "Seslerini doğru ve etkin kullanma"yı öğretmenlerin \%21'i konuşma öğretiminde en çok kullandıkları yöntem olarak belirtmişlerdir. Dramatizasyon yöntemi her ne kadar Türkçe 
Öğretim Programı'nda belirtilmese de ders kitaplarındaki etkinliklerde yer almaktadır. Benzer olarak Aykaç (2011: 97) araştırmasında Türkçe öğretiminde yaratıcı drama etkinliklerinin uygulandığı deney grubu ile öğretmen kılavuz kitabı, öğrenci ders kitabı ve çalışma kitabına dayalı etkinliklere göre öğretim yapılan kontrol grubu öğrencilerinin konuşma becerisi puan ortalamaları arasında deney grubu öğrencilerinin lehine anlamlı fark olduğu sonucuna ulaşmıştır. Öztürk ve Altuntaş (2012: 351) da dramatizasyon etkinliklerinin öğrencilerdeki iletişim, yaratıcılık, empati kurma ve eleştirel düşünme becerilerine katkıda bulunacağı gibi derslerin daha akıcı, zevkli ve öğrenci merkezli geçmesini sağlayacağını belirtmişlerdir.

Konuşma becerisi kazanımlarına dair öğretmen görüşlerinin sıklığı incelendiğinde "Kendini sözlü olarak ifade etme alışkanlığı kazanma" ve "Konuşmalarında beden dilini etkili bir şekilde kullanır." kazanımları öğretmenler tarafından en önemli kazanımlar olarak görülmektedir. Doğan (2009: 291) da konuşma öğretiminde asıl amacın, kişinin duygu ve düşüncelerini başkalarına kimi zaman anında (hazırlıksız olarak), kimi zaman da hazırlıklı olarak rahatıkla ifade edebilmesini sağlamak olması gerektiğini belirtmiştir. Benzer (2015: 44), “Okunan metindeki karakter başka öğrenciler tarafından beden dili kullanılarak canlandırılabilir." şeklinde bir kazanımın müfredata eklenmesinin öğrencilerin hem metni daha iyi anlamalarını hem de eğlenmelerini sağlayacağını belirtmiştir.

Konuşma etkinliklerinin uygulanmasında öğretmenlerin en çok yaşadıkları zorlukların "Materyal çeşitliliğinin az olması" ve "Konuşma etkinliklerinde ön hazırlık, uygulama ve değerlendirme bölümlerinin olmaması"ndan kaynaklandığı görülmüştür. Bu durum konuşma etkinliklerinin yapısının sorgulanmasını gerektiren ciddi bir durumdur. Alanyazında yapılan taramalarda aşamalı biçimde hazırlanmış çeşitli konuşma etkinlikleri (Brown, 1994: 278-282;, Doğan, 2009: 195; Lüle Mert, 2014: 30-31; Kardaş ve Tunagür, 2015: 187) aşamalı biçimde tasarlanmış olsa da bu etkinliklerin materyal çeşitliliği açısından eksik kaldığı görülmüştür.

Konuşma öğretimini geliştirmeyle ilgili öğretmenlerin $\% 85^{\prime} i$ gerçek hayatın içinden seçilmiş otantik konu ve materyallerin konuşma becerisini geliştireceğini ifade etmişlerdir. Otantik materyaller, gerçek hayattaki durumlardan yapay sınıf ortamında yararlanmamızı sağlayan dokümanlardır (Temizyürek ve Birinci, 2016: 56). Brown’a göre (1994: 267) sadece ders kitaplarının kullanılmasıyla öğrencilerin gerçek yaşamda kullanılan dile maruz kalması sağlanamaz. (Richards, 2003:2), öğrenilenlerin kalıcılığının öğrenilenlerin gerçek yaşamın içinden olması ile doğru orantılı olduğunu belirtmiştir. Bu sebeple seçilecek materyaller gerçek yaşamın içinden olmalıdır. Ayrıca 10 yılın üzerinde mesleki tecrübeye sahip dört öğretmenden dördü de konuşma öğretimini geliştirmede "Dramatizasyon (Rol oynama, Tiyatro, Yaratıcı drama, vs.) çalışmalarına yer verilebilir." cevabını işaretlemişlerdir. Üç öğretmenin cevapları arasında geçen "Örnek konuşmalar sınıfta izletilmeli" 
cevabı ise teknolojiyle de birleştirilerek konuşma etkinliklerine yeni bir kimlik kazandırabilecek olması açısından önemlidir.

Konuşma etkinliklerinin Türkçe derslerindeki uygulanma zamanıyla ilgili öğretmen görüşlerinde her ne kadar konuşma etkinliklerinin ders akışı içerisinde yapılması gerektiği fikri (\%55) ağır bassa da azımsanmayacak sayıda öğretmen de (\%40) konuşma etkinliklerinin ayrı bir ders saati içerisinde yapılması gerektiğini belirtmiştir. îki öğretmen (\%5) ise konuşma etkinliklerinin bazen bir ders saati bazense daha kısa sürebileceğini ifade ederek duruma göre değişkenlik gösterebileceğine işaret etmişlerdir. Farklı olarak Gün (2018: 121) tezinde öğretmenlerin yarıdan fazlasının konuşma öğretimi için haftalık iki ders saatini ideal süre olarak gördükleri sonucuna ulaşmıştır. Göğüş'e göre (1978: 177) ise başka konuların işlenişi esnasında konuşma becerisi kazandırmaya çalışmak, sadece birkaç düzeltme ve kısa bir öğütten ibaret kalacağı için konuşma etkinlikleri ayrı bir ders saati içerisinde yapılmalıdır.

2006 Türkçe Dersi Öğretim Programından itibaren (MEB, 2006: 57) her temada birer "dinleme/izleme metni” yer almasına karşın “konuşma metni” kavramı ne 2006 ne de 2018 Türkçe Dersi Öğretim Programında (MEB, 2018: 17) yer almıştır. Bunun yerine konuşma öğretimi, diğer becerilerin içinde verilmeye çalışılmakta yahut ders kitaplarındaki metinlerin arkasında etkinlik sorusu olarak yer almaktadır; ancak konuşma dili içerisinde barındırdığı; jest ve mimikler, tekrarlar, duraklamalar, ses olayları, yarım cümleler, deyimler, yanlış başlangıçlar gibi kendine has özellikleriyle yazı dilinden ayrımaktadır. Konuşma dilindeki bu özellikler "konuşma metni" üzerinden yansıtılabileceği için konuşma öğretiminin odak noktasını "konuşma metni" oluşturmaktadır.

Bu bilgiler ışığında etkinlikler öğrencileri istekli kılma, öğretmen ve öğrenciye rehberlik etme, örnek konuşmalar sunabilme gibi açılardan öğretmenler tarafından yetersiz görüldüğü için bundan sonraki çalışmaların bu eksiklikler göz önünde bulundurularak yapılması gerektiği görülmektedir.

\section{Öneriler}

1. Öğretmen görüşleri incelendiğinde; ders kitabındaki etkinliklerin yetersiz ve tekdüze olduğu, etkinliklerdeki yönergelerin zenginleştirilmesi gerektiği, etkinliklerin öğrencilerin seviyesine uygun olmadığı ve ilgilerini çekmediği görülmektedir. Bu nedenle etkinliklerin aşama aşama olmasının, konuların gerçek yaşamın içinden seçilmiş olmasının, etkinliklerdeki materyal çeşitliliğinin teknoloji aracılığıyla artırılmasının faydalı olacağı görülmektedir.

2. Konuşma öğretimi, günlük yaşamdan alınan konularla beden dili ve sesi etkili kullanma destekli etkinlikler üzerinden öğrencilere verilmelidir.

3. Konuşma becerisinin kazandırılmasında konuşmanın yazılı hâli üzerinden konuşma öğretiminin yapılması konuşma dili özelliklerini yansıtması bakımından önemlidir. Bu sebeple 
etkinliklerde ifadelerin konuşma diline uygun olarak yazıldığı, cümlelerin içinde bol bol tekrarların ve konuşma dilini yansıtacak ögelerin (duraksama ifadeleri, deyimler, ses olayları vb.) yer aldığı metinlere ihtiyaç olduğu görülmüştür. Bu metin türü de henüz Öğretim Programı'nda (MEB, 2018: 17) yer almayan "konuşma metni"dir. Konuşma metni kavramı programa eklenmeli ve konuşma öğretimi bu metinler üzerinden verilmelidir.

4. Konuşma için seçilen materyaller otantik olmalı ve rol model olabilecek otantik konuşma videoları teknoloji yardımıyla öğrencilere izletilmelidir. Bu şekilde öğretmenlerin en çok yakındığı noktalardan olan öğrencilerin konuşmaya karşı kaygısı, isteksizliği azaltılabilir ve etkinlikler öğrenciler için ilgi çekici hâle gelebilir.

\section{Kaynaklar}

Arslan, M. ve Adem, E. (2010). Yabancılara Türkçe öğretiminde görsel ve işitsel araçların etkin kullanımı. Dil Dergisi, 147, 63-86.

Arslan, A. (2012). Üniversite öğrencilerinin topluluk karşısında konuşma ile ilgili çeşitli görüşleri (Ağrı İbrahim Çeçen Üniversitesi örneği). Turkish Studies, 7(3), 221-231.

Aykaç, M. (2011). Türkçe öğretiminde çocuk edebiyatı metinleriyle kurgulanan yaratıcı drama etkinliklerinin anlatma becerilerine etkisi. Yayımlanmamış Doktora Tezi. Ankara Üniversitesi Eğitim Bilimleri Enstitüsü, Ankara.

Benzer, A. (2015). Türkçe öğretiminde beden dili kullanımının öğrenme ve tutum üzerindeki rolü. Hacettepe Üniversitesi Eğitim Fakültesi Dergisi, 30(1), 33-47.

Brown, A. L. (1994). The Advancement of Learning. Educational Researcher, 23(8), 4-12.

Bulut, K., Açık, F. ve Çiftçi, Ö. (2016). Mikro öğretim tekniğinin Türkçe öğretmen adaylarının konuşma becerilerine etkisi. Ana Dili Eğitimi Dergisi, 4(1), 134-150.

Ceran, D. (2012). Türkçe öğretmeni adaylarının konuşma eğitimi dersine yönelik tutumlarının değerlendirilmesi. France: The Journal of Academic Social Science Studies, 5(8), 337-358.

Demirel, Ö. (1999). Türkçe öğretimi. İstanbul: Millî Eğitim Yayınları.

Doğan, Y. (2009). Konuşma becerisinin geliştirilmesine yönelik etkinlik önerileri. Türk Eğitim Bilimleri Dergisi, $7(1), 185-204$.

Erden, B. (2014). Ortaokul Türkçe dersi öğretim programında konuşma eğitimine yönelik olarak önerilen yöntem/tekniklere ilişkin öğretmen görüşleri. Yüksek Lisans Tezi. Abant İzzet Baysal Üniversitesi, Eğitim Bilimleri Enstitüsü. Bolu.

Göçer, A. (2007). Türkçenin yabancı dil olarak öğretiminde kullanılan ders kitaplarının ölçme ve değerlendirme açısından incelenmesi. Dil Dergisi, 137, 30-48.

Göğüş, B. (1978). Orta dereceli okullarımızda Türkçe ve yazın eğitimi, Ankara: Gül Yayıncılık.

Gün, E. (2018). 8. sınıf Türkçe dersi konuşma eğitiminin öğretmen ve öğrenci görüşlerine göre belirlenmesi. Yüksek Lisans Tezi. Erciyes Üniversitesi. Eğitim Bilimleri Enstitüsü. Kayseri.

Katchen, Johanna E. (2004). Teaching Presentation Skills Using Video as Role Model. Ming Hsin University of Science and Technology, 41-50.

Kardaş, M. N. ve Tunagör, M. (2015). 6-8 sınıf öğrencilerinin Türkçe konuşma becerilerini geliştirmeye yönelik etkinlik önerileri. International Journal of Languages' Education and Teaching, 3(2), 183-202. 


\section{Konuşma Öğretiminin Program ve Ders Kitabı Ekseninde Uygulamaya Yansıması}

Kolaç, E. (2003). Illköğretim dördüncü sınıf Türkçe ders kitaplarının öğretmen görüşlerine dayalı olarak değerlendirilmesi. Uludağ Üniversitesi Eğitim Fakültesi Dergisi, 17(1), 105-137.

Kurudayıoğlu, M. (2003). Konuşma eğitimi ve konuşma becerisini geliştirmeye yönelik etkinlikler. Türklük Bilimi Araştırmaları, Türkçe'nin Öğretimi Özel Sayısı, s.296.

Lüle Mert, E. (2014). Türkçenin eğitimi ve öğretiminde dört temel dil becerisinin geliştirilmesi sürecinde kullanılabilecek etkinlik örnekleri. Ana Dili Eğitimi Dergisi, 2(1), 23-48.

Magasic, M. (2017). Learning Through Watching: Streaming Video in L2 English. The Jalt Call Journal, 13(3), 199-209

McDonough, J., Shaw, C. ve Masuhara. H. (2013). Materials and Methods in ELT: A Teacher's Guide. Oxford: Blackwell.

MEB Hizmet İçi Eğitim Yönetmeliği. (1995), Resmi Gazete (Sayı:22161). Erişim adresi: http://mevzuat.meb.gov.tr/dosyalar/324.pdf.

MEB. (2006). İlköğretim Türkçe dersi öğretim programı ve kılavuzu (6, 7, 8. Sınıflar). Ankara: MEB Yayınları.

MEB. (2018). Türkçe dersi öğretim programı (illkokul ve Ortaokul 1, 2, 3, 4, 5, 6, 7 ve 8. Sınıflar). Ankara: Devlet Kitapları Müdürlüğü.

Oradee, T. (2012). Developing speaking skills using three communicative activities (discussion, problem-solving, and role-playing). International Journal of Social Science and Humanity, 2(6), 533.

Özbay, M. (2005). Ana dili eğitiminde konuşma becerisini geliştirme teknikleri. Journal Of Qafkaz University, 16, 177-184.

Öztürk, B. K., Altuntaş, i. (2012). İlköğretim ikinci kademede konuşma eğitimine yönelik öğretmen görüşleri: Nitel Bir Çalışma. Eğitim ve Öğretim Araştırmaları Dergisi, 1(2), 342-356.

Richards, J. C. (1990). The language teaching matrix. Cambridge: Cambiridge University Press.

Richards, J. C. (2003). Current trends in teaching listening and speaking. The Language Teacher. July.

Sever, S. (2004). Türkçe öğretimi ve tam öğrenme. Ankara: Anı Yayıncılık.

Šolcová, P. B. (2011). English Language and Literature and Teaching English Language and Literature for Secondary Schools. Yüksek Lisans Tezi, Masaryk University, Brno

Tavşancıl, E. ve Aslan, A. E. (2001). İçerik analizi ve uygulama örnekleri. İstanbul: Epsilon. Temizyürek, F. (2007). Illköğretim ikinci kademede konuşma becerisinin geliştirilmesi. Ankara Üniversitesi Eğitim Bilimleri Fakültesi Dergisi, 40(2), 113-131.

Temizyürek F. ve Birinci F.G. (2016). Yabancı dil öğretiminde otantik materyal kullanımı. Bartın Üniversitesi Eğitim Fakültesi Dergisi, 5(1), 54-62.

Topçuoğlu, F. (2011). Ana dili öğretiminde beceri alanları. İstanbul: Kerasus Yayınları.

Topçuoğlu, F. (2012). Öğretmen görüşlerine göre konuşma eğitiminde karşılaşılan sorunlar. JASSS, 5(7), 735750.

Tüzemen, T. ve Kardaş, M. N. (2017). Akademik çelişki tekniğinin 6.sınıf öğrencilerinin Türkçe konuşma becerilerine etkisi ve bazı değişkenlerle ilişkisi. YYü Eğitim Fakültesi Dergisi, 14(1), 581-610.

Üner, Ş. (2010). Illköğretim 7. sınıf Türkçe dersi öğrenci çalışma kitaplarındaki etkinliklerin öğrenci seviyesine uygulanabilirliğinin öğretmen görüşleri doğrultusunda değerlendirilmesi (Aksaray ili örneği). Yayımlanmamış Yüksek Lisans Tezi, Selçuk Üniversitesi Eğitim Bilimleri Enstitüsü, Konya.

Yıldırım, A. ve Şimşek, H. (2013). Sosyal bilimlerde nitel araştırma yöntemleri. Ankara: Seçkin Yayıncılık. 


\section{Extended Abstract \\ Introduction}

Speaking skill, which is one of the narrative skills, is the transfer of emotions, thoughts and information through the language of voices after being designed in mind. Conversation, which is one of the four basic skills, is one of the most used skills, but according to the results of the research, it is the least accentuated skill during the education phase.

The question of what is speech has been asked for centuries. However, the issue of how to carry out the training during the implementation phase is still being debated. Specially designed speech activities have a significant role in the further development of children's speaking skills. This raises the question of how the studies in Turkish lessons and the features of the activities in the textbooks are and how the new types of activities will be.

In this study, it is aimed to determine the variables related to speech education and the opinions of Turkish teachers about these variables.

\section{Method}

This research was carried out with phenomenology which is one of the qualitative research designs. In this study, the phenomenon of Turkish teachers' opinions about the studies related to speaking skills in middle school Turkish courses was investigated. Although the questionnaire used in the research was sent in digital format, it is accepted as semi-structured. Because different questions vary according to the answers given in the questionnaire. As the data collection tool of the research consisted of different types of questions, content analysis was used to evaluate the data.

The prepared questionnaire was arranged according to the opinions and suggestions of two teachers and two field experts, and new questions were added and unnecessary questions were deleted. In this questionnaire, 1st, 8th, 9th, 10th and 11th questions are ranking questions; 3rd, 4th, 5th, 6th, 7th and 14th questions are open-ended; 2 nd question was dichotomous question; 12 th and 13 th questions are multianswer multiple choice questions.

\section{Result and Discussion}

In this study, it is aimed to determine the opinions of the Turkish teachers about the studies about speaking education during the course of Turkish lesson.

It was seen in Turkish lessons that the least education was on speaking skills. The reason for this is the lack of instructions, the inability to attract the student's interest, and the fact that the activity is difficult to apply. $20 \%$ of the teachers (11) stated that the most common problem in the activities during the implementation phase was 'not attracting the attention of the students'. It was seen that 'Discussion ' and' Speech Attended ' were used mostly by teachers. It was seen that the difficulties experienced by the teachers in the implementation of the speech activities were due to the lack of material diversity and the lack of preparation, implementation and evaluation parts in the speech activities. It has been suggested by the teachers that the researches and speech activities should be enriched with sample of speeches from the real life and emphasizing the features of the spoken language. 